\title{
Does a sustainable development concept bring a change in transport planning? The case of the implementation of three major infrastructures in Montreal
}

\author{
J.-P. Thouez ${ }^{1,2}$, P. André ${ }^{1} \&$ Y. Bussière ${ }^{2,3}$ \\ ${ }^{1}$ Department of Geography, University of Montreal, Canada \\ ${ }^{2}$ Laboratory for Transport Safety, Interuniversity Research Center on \\ Enterprise Networks, Logistics and Transportation (CIRRELT), Canada \\ ${ }^{3}$ Faculty of Economics, Benemérita Universidad Autónoma de Puebla \\ (BUAP), México, Colegio de Tlaxcala, México
}

\begin{abstract}
In recent years, with a new awareness that almost every development topic relates in some way to sustainability, transportation is likely to be on the top of the list. Discerning strategies to reduce automobile usage to promote walking, public transit use and reduce the amount of daily travel that we all need to do are a key challenge for more liveable and sustainable communities. This paper examines the environmental impact reports and the public reaction to three transportation infrastructures in the region of Montreal. The debate surrounding these projects questioned the interdependency between transportation and land-use, the need for new expressways versus transit supportive systems. Efforts to manage urban growth and transportation in a sustainable way will require well structured public debates and a real regional operating structure shared by the stakeholders.

Keywords: sustainable development, transport planning, public participation, environmental assessment, Montreal.
\end{abstract}

\section{Introduction}

Transportation systems have been a powerful force in determining the shape and character of cities since the mid-nineteenth century. Today our urban 
environments are influenced by the presence of motor vehicles. In an attempt to address the imbalance between the place of motor vehicles and other human needs, western countries have adhered to the concept of sustainable development: the need to balance economic, environmental and equity objectives. The "three Es" as they are known, can be symbolizing the horizontal integration of issues on a single scale of planning and the vertical integration of these objectives across scales of planning. Actions at each level must be seen in terms of their impact on other levels [1,2]. Sustainable transport planning must start with the question: "What is the most appropriate thing to do in order to consume less, or at least to reduce the continual increase in vehicle miles traveled in both absolute and per capita terms". The introduction of the concept of sustainable development into the domain of transportation has led to a number of new ideas: smart growth, growth management, new urbanism, transit oriented development as new ways to organize urban space in order to cut back on the use of the automobile; to promote the expansion of public transport and to protect the environment [3]. However, there is no consensus regarding the question of how to integrate the concept of sustainable development with transport planning, territorial planning and environmental issues. Five case studies undertaken in Europe demonstrate both the role of new governmental organizations for agglomerations, and the importance of the search for consensus, negotiation and pragmatism [4]. The objective of this article is to show how certain road infrastructure projects in Montreal could indicate the existence of a new territorial governance.

\section{The transport infrastructure projects in Montreal}

\subsection{Sustainable transport policies in Quebec}

The Department of Transport of Quebec (MTQ) started a process to establish a transportation plan for the Metropolitan Region of Montreal (RMM) (Figure 1) in March 1995, with the objective of bringing all the participants to agree on an integrated vision of the transport infrastructures to counter urban sprawl. This reflection initiated the implementation of a mobility plan for the RMM [5]. During this period, the government of Quebec implemented a new global management structure for the RMM. In 1995 the Metropolitan Agency of Transportation (AMT) was created to favour the use of public transport. In 2000, the Montreal Urban Community (MUC) was appointed to produce a management and development scheme for the territory. In 2001, the Department of Municipal Affairs (MAM) published a framework of development for the RMM based on sustainable-consolidation principles for urban zones and major economic poles [6]. In 2004, the City of Montreal approved a new plan of urbanism giving priority to public transportation. In this context, several road infrastructural projects were examined by the Quebec Environmental Public Hearing Board (BAPE) concerning the Environmental Impact Assessment and Review Process (PEEIE). In Quebec, road projects have been subjected to the PEEIE since 1978, and eventually to carry out an enquiry and public audiences of the BAPE [7]. 


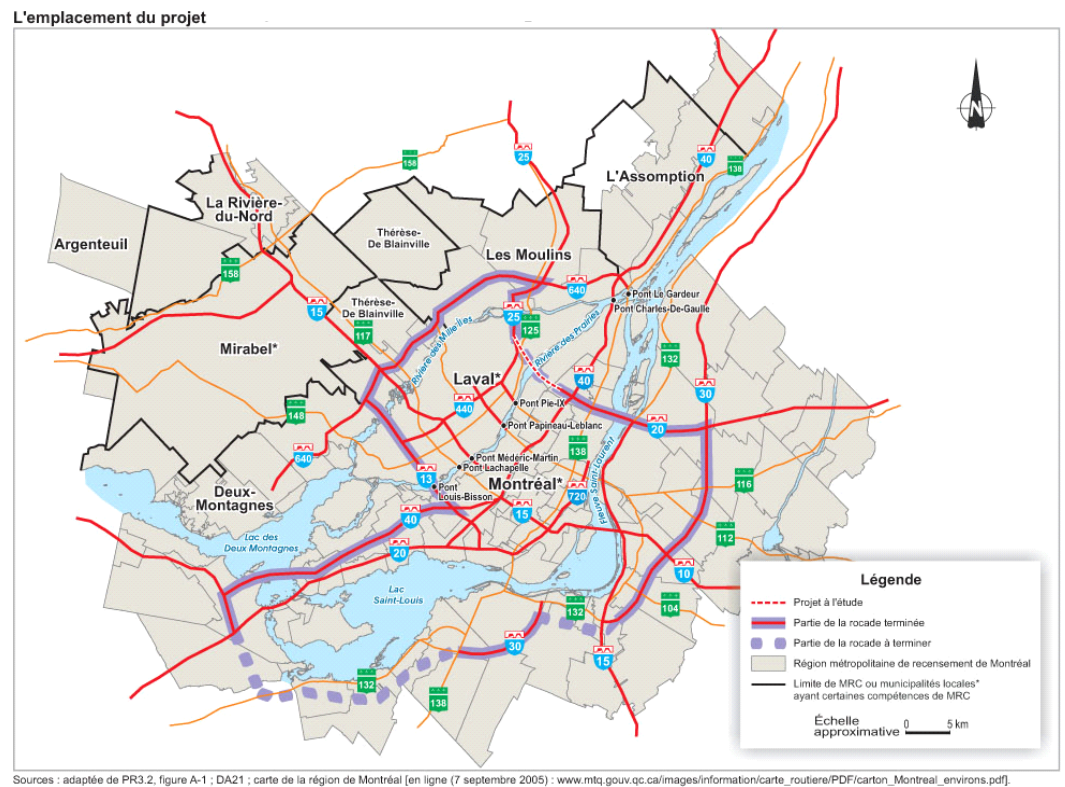

Figure 1: $\quad$ Montreal Metropolitan area.

\subsection{Implementation of bus lanes on the Champlain ice bridge}

The first project examined by the BAPE, at the beginning of the 1990s, (with the implementation on that year of the PEEIE in the RMM) was the establishment of bus lanes (Figure 2) on the Champlain ice bridge [8]. The MTQ project also implied two more developments. General rationalization for the project was supported by the traffic increases between downtown Montreal and the South Shore. The BAPE public audiences held in 1991 showed three major worries for the citizens: potential impacts of the project on the quality of life; substitute options to the MTQ project; and urban sprawl issues. The transport agencies and the municipalities agreed with the project, but the great majority of citizens showed their disagreement. At the end of his analysis, the BAPE issued an unfavourable notice, estimating that that project, as designed by the MTQ, was not the adequate answer to improve the bus service between Montreal and Brossard and that the project did not propose a solution to reduce bridge traffic congestion. Instead, the BAPE proposed an approach taking into account sustainable development supported on two conditions: rebuilding of the present lane on the bridge reserved to buses and improvement of public transport services to reduce traffic congestion. The Department of Environment of Quebec (MENVQ), which recently became the Department of sustainable development of the Environment and Parcs, re-examined the BAPE's arguments and the MTQ project was suspended. However, the construction of this infrastructure is still included in the mobility plan of the MTQ. In January 2001, the MTQ created a 
Consultation Commission concerning the improvement of mobility between Montreal and the South Shore (Nicolet Commission). Following several public consultations, and the deposit of various studies financed by the MTQ, the Nicolet Commission recommended in its final report to quickly take action in the Champlain corridor axis by enlarging the Honoré-Mercier bridge for public transportation and trucking and to plan the completion of the Montreal expressway networks in the middle term with a new link between expressways 640 (North Shore) and 30 (South Shore) East of the RMM (figure 3) and to improve parking and toll management [7]. Even though Travel Demand Management Measures may prove efficient to solve traffic congestion and serve as an alternative to new infrastructures [9] such measures are politically difficult to implement and bypassed by proposals of new infrastructures.

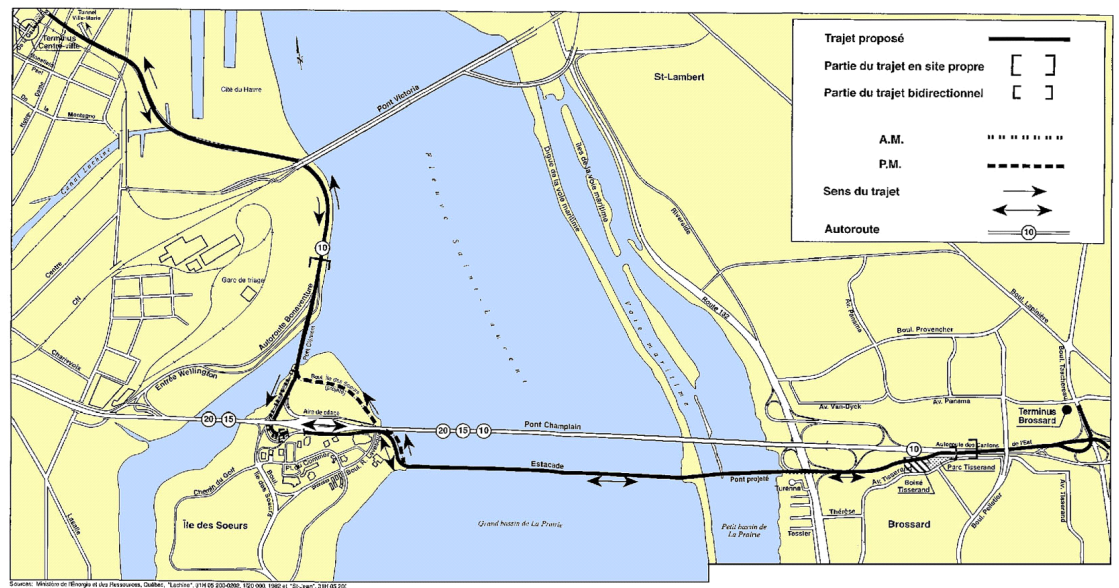

Figure 2: $\quad$ Implementation of bus lanes on the Champlain ice bridge.

\subsection{Autoroute 30}

This project consisted in linking the South Shore urban and industrial poles to the RMM. Three sections were built in the 1960s without an impact study public debate. During the 1980 s, the project was modified so that the infrastructure would be transformed into a by-pass road for transit traffic on the island of Montreal. Since then, three other sections were examined by the BAPE. The first section, $12 \mathrm{~km}$ between A10 and A15 (Figure 3) was subjected to a governmental mediation, and the MTQ, without public audiences, negotiated between the parties the modalities for this section [10]. This road segment was rapidly executed and opened in 1996. The West section, $35 \mathrm{~km}$ between Chateauguay and A20, was subjected to an enquiry and public audiences [11]. Despite the opposition of environmental groups, the BAPE concluded that the layout generally created the least important environmental impact, and that the 


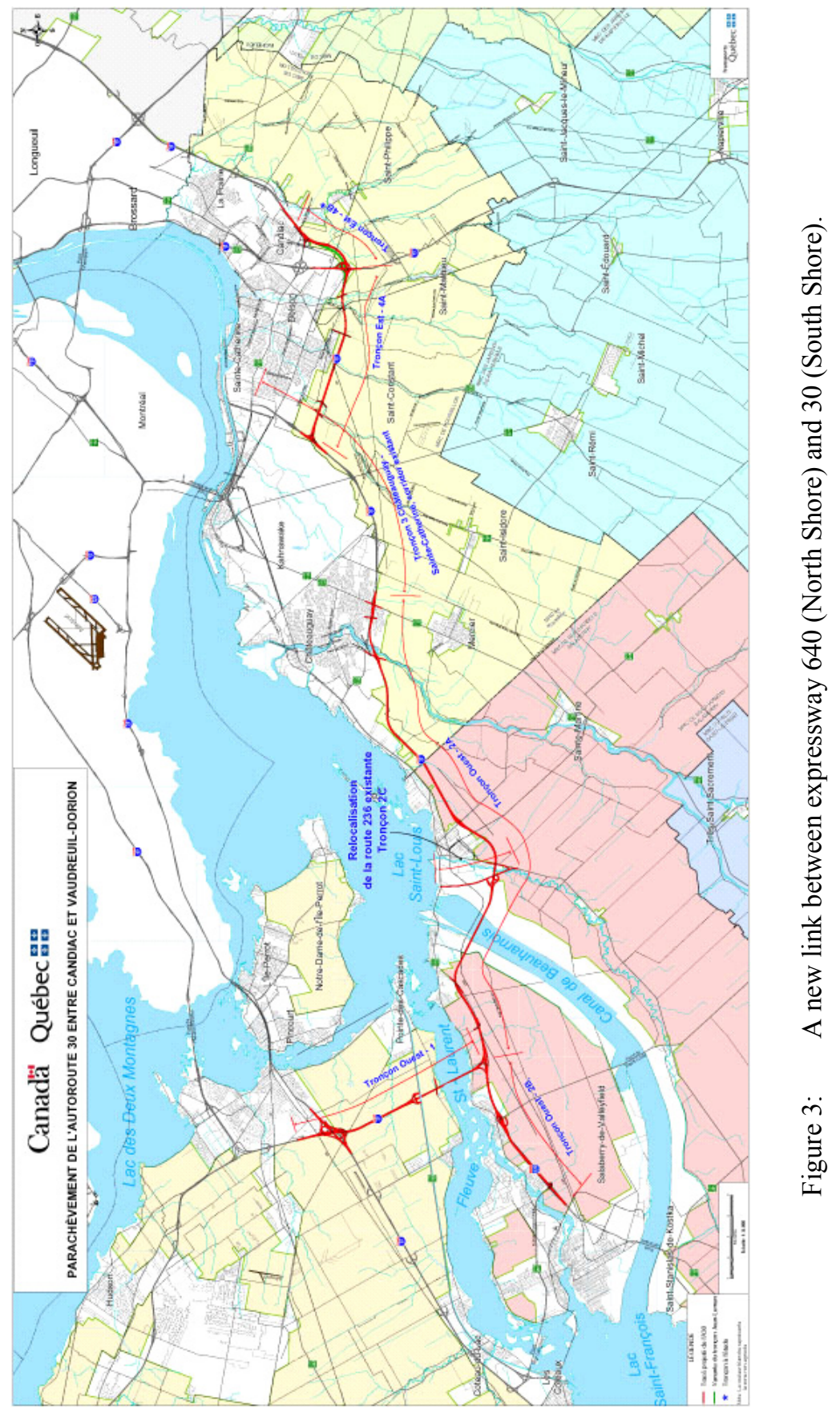


punctual impacts could be resolved by the promoter. In 1999, the MENVQ authorized the project. The East section, between Sainte-Catherine and A15 was subjected to an enquiry and public audiences during the summer of 2002 [12]. To build this section, between two other sections already built, the MTQ proposed two options: an urban layout (North option) in the axis of the present road and a rural layout (South option). In response to the opposition of farmers and of the Commission de la protection du territoire agricole du Québec (CPTAQ), the BAPE, following environmental analysis of the MENVQ, approved the urban layout. This section should be built in a public-private partnership (PPP).

\subsection{Extension of expressway 25}

It consisted in extending A25, between A440 in Laval and the existing section in Montreal (Figure 4). The construction of this six lane expressway, with a length of $9 \mathrm{~km}$ will necessitate the building of a bridge on the Rivière des Prairies and should include a corridor for public transport. This project should be executed and financed in PPP. During the public audiences of the BAPE, the participants noted the absence of a sustainable development plan in the study of impact. The study was alleviated by the MTQ because it wanted to offer maximum latitude to the eventual promoter. The PPP formula is recent in Quebec in the area of road building. The participants were divided between those who supported the project in the name of the economic development in the East of Montreal and those who wished to decrease automobile traffic. The BAPE explained both arguments in its 2005 report [13] and mentioned that the eventual impacts and attenuation measures were the responsibility of the MENVQ.

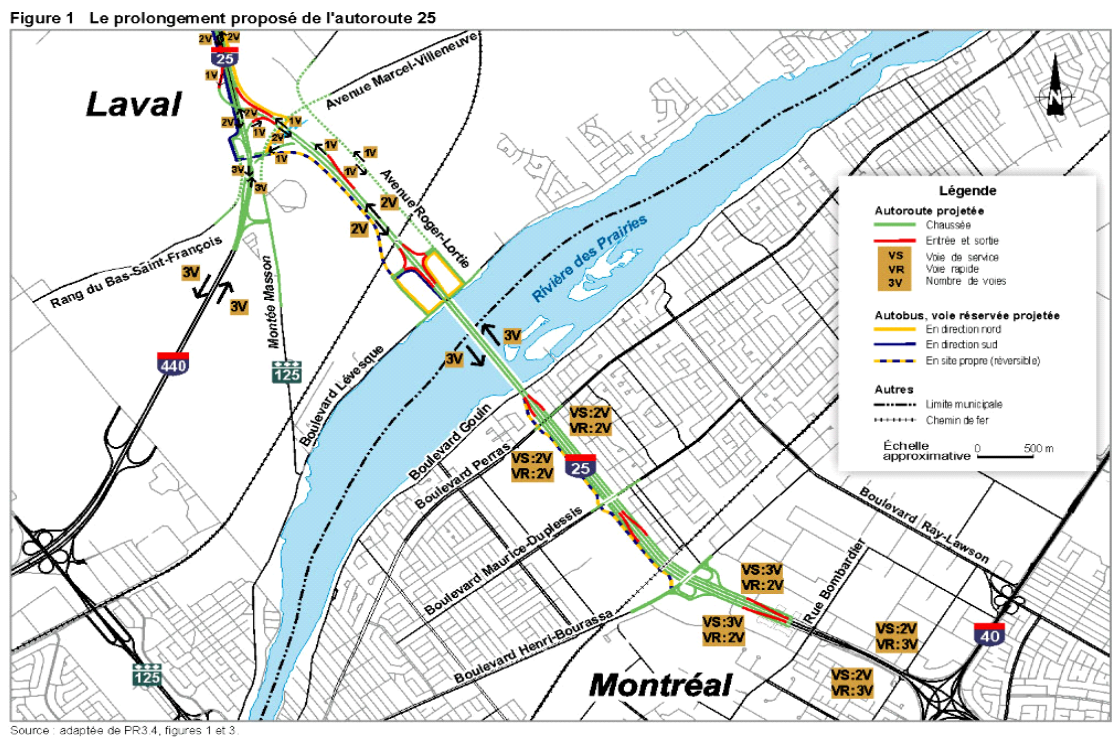

Figure 4: $\quad$ Extension of expressway 25. 


\section{What lessons can we learn?}

\subsection{The projects show new governance}

The first project described above was challenged and blocked by the frontage owners. New regional actors also appeared, including the City of Montreal. The possibility that including private interests will not serve as a pretext for the MTQ to take over the control of the project should be examined. The studies of the Nicolet Commission preceded the road planning; this type of approach has the advantage of studying the global challenges but may delay their implementation. The second project is a special case: debates and negotiations were conducted according to the "salami" technique [7]. For the third project, the MENVQ will execute or supervise the supplementary impact studies in the New PPP environment.

\subsection{Sustainable development and transport}

The first lesson from the public debates is that the concept of sustainable development is becoming more and more a frame of reference for public local action. The second lesson: the public debates show that bad coordination between the government departments or agencies and the fragmentation of the public actors. In this context, application of sustainable development supposes institutional and procedural innovations. Implementation of a real regional operating structure shared between the public actors; on the other hand, by taking action too late in the decisional process, the BAPE debates triggered conflicts putting public interests in a retroactive position.

\section{Conclusion}

The MTQ should continue to place the concept of sustainable development in the centre of its preoccupations. According to 2002 data, transportation represents more than $38 \%$ of greenhouse gas emissions (GES) in Quebec. The question of the integration of transportation, development, and environment in a perspective of sustainable development must always be present in local public action. The cases described show that we must be able to define a priori this concept to avoid that each project be subjected to piecemeal arbitrations between contradictory objectives and diverging interests.

\section{References}

[1] Vivien, F.D. Histoire d'un mot, histoire d'une idée: le développement durable à l'épreuve du temps. Jolivet M. (dir). Le développement durable, de l'utopie au concept, Paris, Elsevier: 19-60, 2001.

[2] Wheeler, S.M. Planning for sustainability, Routledge. Taylor \& Francis Group, 2004. 
[3] OCDE. Intégrer les transports dans la ville: réconcilier les dimensions économiques, sociales et environnementales. Paris: Organisation de coopération de développement économique, 2000.

[4] Jouve B. Dr. Les politiques de déplacements urbains en Europe: l'innovation en question dans cinq villes européennes, Paris: L'Harmattan, 2003.

[5] Québec. Plan de gestion des déplacements: région métropolitaine de Montréal. Pour une décongestion durable, Québec: Ministre des Transports, Ville de Montréal (2004). Montréal au premier plan. Plan d'urbanisme de Montréal, version préliminaire, 2000.

[6] Québec. Cadre d'aménagement et orientations gouvernementales: région métropolitaine de Montréal 2001-2021, Sous-ministeriat aux politiques et à la concertation métropolitaine, Ministère des Affaires municipales de la métropole, 143 pages, 2001.

[7] Gauthier M. La planification des transports et le développement durable à Montréal: quelles procédures de débat public pour quelles solutions intégrées? Flux 60\61 :50-63, 2005.

[8] BAPE. Implantation de voies réservées sur l'estacade, région de Montréal, Bureau d'audiences publiques sur l'environnement. Rapport d'enquête et d'audience publique, $\mathrm{n}^{\circ}$ 54, 183 p., 1982.

[9] Bussière Y., P. Lewis, M.-H. Vandersmissen, P.Y. Villeneuve, Travel demand forecasting and TDM measures: the example of the South Shore, 2002-2021, Urban Transport 2003, Southampton, WIT Press, 2003.

[10] BAPE. Prolongement de l'autoroute 30 entre les autoroutes 10 et 15 , Bureau d'audiences publiques sur l'environnement, Rapport d'enquête et de médiation, nº 61, 34 p. et annexes, 1993.

[11] BAPE. Prolongement de l'autoroute 30 entre Chateauguay et l'autoroute 20 dans la MRC de Vaudreuil-Soulanges, Bureau d'audiences publiques sur l'environnement, Rapport d'enquête et d'audience publique, $\mathrm{n}^{\mathrm{O}} 122$, 133 p., 1998.

[12] BAPE. Projet de construction de l'autoroute 30 de Sainte Catherine à l'autoroute 15, Bureau d'audiences publiques sur l'environnement, Rapport d'enquête et de médiation, $\mathrm{n}^{\circ} 164,101$ p., 2002a.

[13] BAPE. Projet de prolongement de l'autoroute 25 entre l'autoroute 440 et le Boulevard Henri-Bourassa, Bureau d'audiences publiques sur l'environnement, Rapport d'enquête et de médiation, nº 215, 128 p., 2005. 